DOI https://doi.org/10.30525/978-9934-26-173-2-32

\title{
ІМІДЖ І ПРОФЕСІЙНЕ ЗРОСТАННЯ ПЕДАГОГА В СУЧАСНИХ УМОВАХ СУСПІЛЬСТВА
}

\author{
Поліщук Н. В. \\ доктор філософських наук, \\ доиент кафедри професійної освіти, трудового навчання \\ та технологій \\ Рівненський державний гуманітарний університет \\ Мальованчик В. В. \\ учителька украйнської мови та літератури, \\ Рівненська ЗОШ I-ІІІ ступенів № 28 Рівненської міської ради \\ м. Рівне, Украӥна
}

Сучасне суспільство характеризується стрімким розвитком науковотехнічного й інформаційного прогресу, який суттєво впливає не лише на матеріальне виробництво, а й на всі сфери життєдіяльності людини, яка $\epsilon$ основною продуктивною силою суспільства. Глибоких змін зазнає освітня галузь, яка повинна постійно підлягати модернізації та підлаштовуватися під процес уже віртуального освітнього середовища. Але це зумовлює глибинні соціальні наслідки, включаючи все, що пов'язане 3 багатоманітністю духовного виробництва, 3 творчою діяльністю та складними соціокультурними процесами. Відбулася суцільна інтелектуалізація та інформатизація всіх видів праці, змінилися технології діяльності вчених, педагогів і всіх сфер інтелектуальної творчості, змінилися як умови праці, так і ставлення до професій, особливо такі зміни відчула професія педагога, імідж і престижність якої знаходиться на низькому рівні.

Концепція розвитку педагогічної освіти передбачає вдосконалення системи освіти для створення бази підготовки педагогічних працівників нової генерації, створення умов для залучення до педагогічної діяльності фахівців інших професій та забезпечення умов для становлення й розвитку сучасних альтернативних моделей безперервного професійного та особистісного розвитку педагогів, які стануть ключовою умовою впровадження Концепції реалізації державної політики у сфері реформування загальної середньої освіти «Нова українська школа» на період до 2029 року [1]. Також важливим завданням держави у цьому напрямку є забезпечення притоку до сфер освіти осіб, які мають бажання й здатні до здійснення позитивних змін. Для цього держава сприяє 
диверсифікації шляхів доступу до педагогічної професії, забезпечуючи розмаїття моделей та програм як формальної педагогічної освіти, так i неформальної та інформальної освіти. Формування якісного контингенту здобувачів педагогічної освіти потребує розгортання системи спеціальних заходів для професійної орієнтації молоді та популяризації педагогічної діяльності [1]. Над підвищенням іміджу професії педагога повинні працювати в комплексі як державні й місцеві органи влади та всі заклади дошкільної, загальної середньої, позашкільної, професійної (професійнотехнічної), фахової передвищої, спеціалізованої освіти відповідних рівнів та вищої педагогічної освіти [1], так і суспільство в цілому.

Але дійсність поки що інша: молодь не бажає навчатися в педагогічних закладах освіти через низькі оплату праці та імідж професії педагога, які вони бачили протягом навчання в школі, натомість масово виїжджає за кордон на заробітки на найменш оплачувані види робіт, стаючи практично рабами в чужій країні, адже бажання швидко заробити великі гроші перекреслює будь-яку гідність і повагу до своєї особистості; у всіх 3МІ піднімають питання булінгу в закладах освіти, але мовчать про зневажливе ставлення учнів, батьків, колег, керівництва до самих педагогів, які змушені мовчати про такі проблеми, боячись ще більшого тиску і приниження або ж звільнення; низька заробітна платня, відсутність доплат, зокрема й за престижність професії, через що педагог відчуває себе фінансово незахищеним, не може дозволити собі літній відпочинок і оздоровлення (ще й під час відпустки змушений іти на підзаробітки, щоб хоч якось підняти фінансовий стан); ніхто не переймається культурним і духовним розвитком педагога, практично відсутні просвітницькі тури по Україні й закордоном, участь у міжнародних конференціях для обміну досвідом, майстер-класах, тренінгах тощо (хіба що за власний рахунок); педагоги закладів освіти всіх рівнів завантажені бюрократією й «паперотворчістю». Зокрема, основними причинами за бюрократизованості шкільної освіти, на думку директорів українських шкіл є діяльність служб, установ та організацій, які навантажують школи всілякими "терміновими заходами"; традиційна бюрократична вертикаль із паперообігом; застарілий стиль управлінського мислення працівників органів управління освітою; неготовність управлінців у системі освіти до застосування безпаперових технологій управління та засад е-врядування; корумпованість освітньої системи, яку підсилює iii централізованість [2]. Така ж бюрократична завантаженість і в працівників закладів вищої освіти, ще й навантаження викладача складає 10-12 навчальних дисциплін. 
3 іншої сторони державна освітня політика робить усі зусилля на забезпечення трансформації педагогічної освіти й забезпечення іiі випереджувального розвитку. Відповідно до цього, рівень освіченості педагогічної спільноти повинен неперервно зростати за рахунок підвищення освітнього рівня молодих фахівців, а також особистісного розвитку педагогічних працівників. Усі здобувачі освіти мають отримати доступ до найсучасніших знань, які можуть бути опановані ними на відповідних освітніх рівнях, та освітніх методик (технологій), що потребує невідкладної належної підготовки та вдосконалення педагогічних працівників. Педагогічним працівникам закладів освіти має надаватись моральне та матеріальне заохочення для підвищення їхнього освітнього рівня [1].

На думку Тетяни Борової, питання розвитку професіоналізму працівників освітньої сфери постають у зв'язку зі змінами та трансформаціями, що відбуваються зараз у суспільстві, зокрема в освіті. Насамперед, суспільство сталого розвитку вимагає від викладачів (вчителів - автор) постійного руху та професійного зростання, навчання студентів (учнів - автор) у відповідності з потребами сьогодення. За таких обставин науково-педагогічний працівник змушений постійно адаптуватися до умов, які змінюються, 3 одного боку, а 3 іншого працювати на майбутнє країни. Тому найважливішим завданням $\epsilon$ допомога науково-педагогічним працівникам у подоланні цих викликів, беручи до уваги особистість викладачів, їхні професійні інтереси, погляди $[3$, с. 6], а, особливо, матеріальне, фізичне та духовне становище.

Отже, успішна професійна діяльність педагогічного працівника вимагає безперервного навчання в умовах динамічних змін та здатності адаптуватися до них, а професійний розвиток має бути спрямований на реалізацію педагогічним працівником себе як особистості. Прагнення до самовдосконалення й самоосвіта $€$ важливими чинниками професійного зростання педагога, що забезпечують розширення його професійних можливостей, пізнавальних інтересів та формування творчої індивідуальності. Ця діяльність, яка має бути постійною та систематичною, нерозривно пов'язана 3 професійним зростанням і підвищенням рівня педагогічної майстерності [1].

Згідно досліджень І. С. Жердєвої та С. С. Рашидової, класичний педагогічний імідж або образ педагога як взірця для наслідування студентами (учнями - автор) формується поступово, охоплюючи як внутрішні, так і зовнішні якості особистості, що потребують цілеспрямованого формування, розвитку й вдосконалення. Успішне застосування іміджу передбачає знання вихідних психолого-педагогічних принципів, 
що обумовлюють його. В якості таких можуть бути: принцип гармонії візуального образу, принцип комунікативності - різноманіття форм i способів інформаційної взаємодії, принцип саморегуляції й ортобіозу (наука про технології самозбереження тіла і душі), принцип мовної діï. Вони виступають у ролі постійних факторів, майстерно втілених у різноманітних формах і методах вдосконалення професійної майстерності [4, с. 59].

Отже, імідж і професійний розвиток педагога тісно пов'язані 3 економічним розвитком держави (фінансування професії педагога закладів освіти всіх рівнів акредитації має бути на найвищому рівні, а не навпаки, як на Рівненщині, де працівники освіти мають найнижчу i нижчу за середній рівень заробітну плату [5]); 3 правовим захистом як педагогів, так і студентів педагогічних закладів (авторитет і повага до професії вчителя повинні формуватися як із боку керівництва закладу й колег, так і з боку батьків та учнів/студентів); із формуванням іміджу закладів освіти (наприклад, запровадження в освітній процес підготовки педагогів обов'язковий освітній компонент «Іміджелогія»). Наведене вище сприятиме авторитету та престижності професії педагога, адже фінансова та правова забезпеченість створять впевненість як у житті, так і у виборі професії, дозволить позбутися виснаженості, психологічного та професійного вигоряння й у комплексі сприятимуть формуванню позивного особистого іміджу педагога, підняттю престижності професії, i, відповідно, зростатиме імідж закладів освіти. Зі свого боку за таких умов педагог буде зацікавлений у підвищенні своєї майстерності та педагогічно-професійних якостей, а також працюватиме над своєю мобільністю та залученням в освітній процес інноваційних технологій навчання, зможе нести відповідальність за власний неперервний професійний розвиток, тобто матиме можливість як для професійного так і для особистого творчого духовного розвитку.

\section{Література:}

1. Концепція розвитку педагогічної освіти. URL: https:// mon.gov.ua/ua/npa/pro-zatverdzhennya-koncepciyi-rozvitku-pedagogichnoyi-osviti

2. Українська школа потерпає від освітянської бюрократії, - опитування Громадянська Освіта. 2013. URL: https://osvita.khpg.org/index.php?id=1372602049

3. Борова Т.А. Розвиток професіоналізму у науково-педагогічних працівників через коучингово-моніторингову технологію адаптивного управління. Імідж сучасного педагога. 2019. № 5 (188). С. 6-11. 
4. Жердєва I.C., Рашидова С.С. Методика формування іміджу викладача вищої школи. Духовність особистості: методологія, теорія і практика. 2016. № 4 (73). С.48-61.

5. Найбільше мають лісівники, значно менше - вчителі та медики: в кого та які зарплати на Рівненщині. URL: https://rivne.media/news/ naybilshe-mayut-lisivniki-znachno-menshe---vchiteli-ta-mediki-v-koho-tayaki-zarplati-na-rivnenshchini

DOI https://doi.org/10.30525/978-9934-26-173-2-33

\title{
ІННОВАЦІЙНА ДІЯЛЬНІСТЬ ПЕДАГОГА ЯК СКЛАДОВА СУЧАСНОГО ОСВІТНЬОГО ПРОСТОРУ: ФІЛОСОФСЬКО-ОСВІТНІЙ АСПЕКТ
}

\author{
Славінська О. М. \\ аспірантка \\ КЗВО «Одеська академія неперервної освіти Одеської обласної ради» \\ м. Одеса, Україна
}

Для XXI століття характерною є доволі-таки стрімка та глибинна модернізація всіх сторін суспільного життя. Зауважимо, що надзвичайно швидко змінюються тенденції щодо утворення єдиного світового, принаймні європейського, економічного та освітнього простору 3 певного аспекту. А от $з$ іншого аспекту, на рівні держави зростають ті чинники, основу яких складають такі культурно-національні особливості, як духовність, ментальність, історична спадщина та освіченість народу. Нині, розвинені суспільства мають на меті реалізувати та організувати навчально-виховний процес таким чином, аби левова частка їхньої спільноти протягом певного часу отримала статус всебічно розвинених особистостей, які б зуміли досягти високого рівня розвитку.

Саме тому трансформаційні процеси та неперервна інформаційна змінність зумовлюють включення людини в складну систему суспільних взаємовідносин, потребують від неї здатності та вміння реалізації нестандартних і швидких рішень. Виходячи із цього, у підходах до навчально-виховної діяльності, вагома увага має приділятися питанням подолання консерватизму, а також існуючих стереотипів педагогічної праці та процесу мислення як в учасників навчання і виховання, так і у освітян. 